\title{
ROLE OF SUGARS IN SURFACE MICROBE-HOST INTERACTIONS IN GROUP B STREPTOCOCCUS INVASION
}

\author{
MANJU O PAI ${ }^{1,2 *}$, VENKATESH $S^{3}$, PRATIMA GUPTA ${ }^{2}$, ANURADHA CHAKRABORTI ${ }^{1}$ \\ ${ }^{1}$ Department of Experimental Medicine and Biotechnology, Post Graduate Institute of Medical Education and Research, Chandigarh, India. \\ ${ }^{2}$ Department of Microbiology, All India Institute of Medical Sciences, Rishikesh, Uttarakhand, India. ${ }^{3}$ Department of Medicine, All India \\ Institute of Medical Sciences, Rishikesh, Uttarakhand, India. Email: manjuohripai@gmail.com
}

Received: 30 August 2019, Revised and Accepted: 03 February 2020

ABSTRACT

Objective: Metabolic sources for food play a very important role in developing a niche for a microbe to invade and cause infection in the host. The influence of various sugars on invasion of Streptococcus agalactiae or Group B streptococcus (GBS) into HeLa and A549 cells in vitro were evaluated.

Methods: The cell lines and the bacteria were pretreated separately with different sugars before invasion. These observations were also corroborated with light microscopy.

Results: Our results showed that the maximum GBS invasion observed at $2 \mathrm{~h}$, decreased significantly $(\mathrm{p}<0.05)$ when the cells were pretreated with $\mathrm{N}$-acetyl galactosamine (GlcNAc), D-xylose, sucrose, lactose, D-mannose, and D-glucose. In contrast, mannitol was seen to support the invasion of GBS. In addition, when a combined effect of GlcNAc and xylose was studied, 87.5\%-91\% inhibition to GBS invasion was observed in HeLa and A549 cell lines, respectively. A sizeable reduction in invasion was observed when the bacteria were pretreated with $10 \mathrm{mM}$ of D-Glucose (79.32\%), GlcNAc (69.66\%), and mannose (48.28\%). In conclusion, GlcNAc, D-xylose, and D-glucose proved to be excellent inhibitors to GBS invasion. Furthermore, bacterial pretreatment results might indicate that these sugar specific receptors might be present on the epithelial cells which possibly gets blocked and thus inhibits the entry of GBS.

Conclusion: These findings are the first to suggest the role of these sugars as a way to alternative therapies to GBS infection by altering the hostpathogen environment during invasion.

Keywords: Group B Streptococcus, Invasion, Oligosaccharide, Blood-brain barrier.

(C) 2020 The Authors. Published by Innovare Academic Sciences Pvt Ltd. This is an open access article under the CC BY license (http://creativecommons. org/licenses/by/4. 0/) DOI: http://dx.doi.org/10.22159/ajpcr.2020.v13i4.35530

\section{INTRODUCTION}

Successful colonization of a host by bacterial microbe is a complex event usually involving a microbe-encoded ligand and a eukaryotic receptor [1]. Once the microbe makes an entry into the host cell, the next step is to dwell and depending on where in the host an invading bacterium takes up residence, the sources of food available within that niche will determine whether that microbe can successfully establish itself. For a long time, carbohydrates were believed to serve solely as a source of energy and as structural moieties but now it is known that many pathogenic microorganisms employ adhesins to bind carbohydrate chains of glycoconjugate on host tissues as their initial step in colonization and invasion. The first line of defense against these infectious microbes consists of decoy oligosaccharides in the mucous layer of epithelial cells $[1,2]$. It has been suggested that interference in this process, particularly by carbohydrates or homologs could be an effective means of interrupting the course of infection and potentially its transmission [3-6]. This mechanism could be exploited as a means to prevent colonization and invasion.

Group B streptococcus (GBS) is the most common cause of neonatal bacterial meningitis in the United States, Europe, and Asia [7]. It is known to cause serious illnesses in diabetics and patients with liver diseases (Mayo Clinic update, 2019). GBS has the ability to attach to buccal epithelial cells of adults, neonates, infants, and cause invasive infections [8]. Streptococci has the ability to adhere to a variety of eukaryotic cellular structures, including laminin, fibronectin, fibrinogen, cytokeratin, and plasminogen [9]. This adherence is thought to be mediated by a number of bacterial moieties such as laminin-binding proteins, C5a peptidase, glyceraldehyde phosphate dehydrogenase, $\alpha$-enolase, and lipoteichoic acid [10]. Recently, a study by Chang et al. [11a] demonstrated that GBS expresses a specific protein on its surface that can bind to glycosaminoglycans on the surface of brain capillary cells, initiating infection of the blood-brain barrier.

This study is in continuation to one of our recently published studies, which shows the role of a cytosolic protein in invasion inhibition of GBS in epithelial cells [11b]. This study also attempts to define the role if any, of carbohydrates as receptors for adherence and invasion of GBS, with the goal of developing possible therapeutic molecules in host-pathogen interaction and help identify targets to prevent invasion which would help understand the host-pathogen interaction at a molecular level.

The uses of soluble carbohydrate receptors as anti-adhesive and anti-invasive agents for GBS infection. This data might also add on to understanding the predilection of the pathogen to breach the BBB which is a critical goal of molecular pathogenesis investigations.

\section{METHODS}

\section{Bacterial strains and growth conditions}

GBS (serotype III) from the blood of a neonate born with early-onset sepsis was taken. The samples were collected from the Department of Obstetrics and Gynaecology and the Department of Pediatrics, Post Graduate Institute of Medical Education and Research (PGIMER) Chandigarh. The Institution's Ethical Committee (PGIMER, Chandigarh) approved this study vide Ethical Clearance No. VS/1619, Dairy No. 7951-53. The isolate was grown on blood agar plates and type identified using a Streptex kit (Difco Ltd.). BAA-22, an ATCC type III GBS strain, was used as a standard in all the studies. Bacteria were grown to 
mid-log phase in Todd-Hewitt broth (THB) with $2 \%$ yeast extract (YE) and aerated at $37^{\circ} \mathrm{C}$ to an optical density at $600 \mathrm{~nm}$ of 0.3 (equal to $\sim 10^{6}$ $\mathrm{CFU} / \mathrm{ml}$ ) for all the assays.

\section{Materials}

Saccharides such as different sugars and its compounds D-mannose, D-glucose, sucrose, lactose, maltose, D-xylose, D-galactose, mannitol, and $\mathrm{N}$-acetyl galactosamine (GlcNAc) at different concentrations $(1 \mathrm{mM}$, $5 \mathrm{mM}$, and $10 \mathrm{mM}$ ) were prepared in phosphate buffer ( $\mathrm{pH}=7.2)$ and in culture media $(\mathrm{pH}=7.2)$ for pretreatment of the cell lines at different time course before and during the bacterial invasion.

\section{Epithelial cell culture}

Epithelial cell lines were obtained from the National Centre for Cell Culture, Pune, India. The A549 cell line was derived from a human lung carcinoma which has many characteristics of Type II alveolar pneumocytes. A549 cells were propagated in Hams F-12 nutrient mixture with 10\% (vol/vol) fetal calf serum (FCS) (Sigma Chemicals, USA), $1 \mathrm{mM}$ glutamine, $100 \mathrm{U}$ of penicillin per $\mathrm{ml}$ and $100 \mu \mathrm{g}$ of streptomycin per $\mathrm{ml}$, and $\mathrm{pH} 7.4$ in humid atmosphere at $37^{\circ} \mathrm{C}$ with $5 \% \mathrm{CO}_{2}$. HeLa cells, a cervical epithelial cell line, were cultured in (Dulbecco's Minimal Essential Medium, Sigma, USA) under similar conditions. Tissue culture cells were grown in 12, 24, and 96 well tissue culture plates (Nunc). Viable cell counts were determined with $0.4 \%$ trypan blue exclusion and counted on a hemocytometer [12]. Monolayers formed were washed 3 times with phosphate buffer saline (PBS) and fresh culture medium was added immediately before assay.

\section{Epithelial cell invasion assays}

Intracellular invasion of A549 and HeLa cell monolayers (passages, $<3$ ) was assayed by a modification of gentamicin protection assay by Murugesan and Rani [6]. Bacteria were grown to an optical density at $600 \mathrm{~nm}\left(\mathrm{OD}_{600}\right)$ of 0.4 in THB with $2 \%$ YE and centrifuged (Remi) at $7000 \times \mathrm{g}$. The pellet was washed twice in (PBS, pH 7.2) and resuspended in Hams F-12 tissue culture medium containing 10\% FCS. GBS were inoculated onto cell monolayers at $2.5 \times 10^{6} \mathrm{cfu} / \mathrm{ml}(\mathrm{MOI}=10: 1)$ and allowed to incubate for $2 \mathrm{~h}$ at $37^{\circ} \mathrm{C}$ in $5 \% \mathrm{CO}_{2}$. Subsequently, the extracellular bacteria were removed by washing 4 times with PBS. Tissue culture medium with penicillin $(5 \mu \mathrm{g} / \mathrm{ml})$ and gentamicin $(100 \mu \mathrm{g} / \mathrm{ml})$ was added to the infected monolayers for $2 \mathrm{~h}$ at $37^{\circ} \mathrm{C}$ to kill any remaining extracellular bacteria. The medium was removed, the monolayers were washed as described above, the cells were lysed by treatment with $100 \mu \mathrm{l}$ of $0.25 \%$ trypsin, and then $400 \mu \mathrm{l}$ of $0.025 \%$ Triton X-100 in PBS was added. The lysate was transferred to $1.5 \mathrm{ml}$ Eppendorf Tubes and vortexed vigorously for $10 \mathrm{~s}$ to disrupt streptococcal chains, as checked by gram staining. Aliquots of the lysates were prepared in PBS and quantitatively plated on blood agar plates to quantify the number of live intracellular bacteria. Experiments were performed in triplicates and replicated 3 times keeping in mind the plate to plate variability. The percentage of internalized bacteria was calculated as ([CFU/well after antibiotic treatment]/[CFU originally added to the well] $) \times 100 \%$

\section{Microscopic enumeration}

Confluent A549 cells were harvested by adding $0.5 \mathrm{ml}$ of $0.25 \%$ Trypsin-EDTA solution (Sigma) and incubating for $15 \mathrm{~min}$ at tissue culture conditions. Trypsin was inactivated with $0.5 \mathrm{ml}$ of FBS. Cells were then seeded onto 12 -mm diameter glass coverslips in 24well tissue culture plates (Falcon) at approximately $2.5 \times 10^{6}$ viable cells per well, and $500 \mu \mathrm{l}$ of Hams-F12 supplemented with $10 \%$ FBS was added to each well. Plates were incubated under tissue culture conditions overnight or until the confluency was reached. Experiments with the treatment of different sugars were performed after washing the monolayer with the culture medium. Adhered cells were fixed with $100 \%$ methanol for $20 \mathrm{~min}$ and stained with $10 \%$ Giemsa for $15 \mathrm{~min}$. The slides were then washed once with sterile distilled water and dried overnight at room temperature. Coverslips were mounted on microscope slides and observed under a phasecontrast microscope (Olympus) at $\times 320$ [13].

\section{Invasion inhibition assay}

Here, the cell lines and the bacteria were treated with different sugars at different time intervals for $30 \mathrm{~min}$ and $1 \mathrm{~h}$ before infecting them with GBS. The experimental results were expressed with respect to the standard strains of GBS (BAA-122) as a positive control and untreated cells incubated and washed with (PBS, $\mathrm{pH}=7.2$ ) as a negative control [14]. Relative percent internalization was calculated as follows: ([number of CFU invaded into cells after treatment with different sugars or at different $\mathrm{pH} /$ number of CFU invaded into untreated control cells] $\times 100 \%$ ).

\section{Statistical analysis}

The variation of the distribution was obtained by calculating the standard error of the mean. The significance of differences between means was analyzed using Student's " $t$ " test. The level of significance was considered as ${ }^{*} \mathrm{p}<0.05$.

\section{RESULTS}

GBS invasion of epithelial cells

The ability of GBS to enter epithelial cells in cultured monolayers of the human alveolar epithelial cell line HeLa and A549 was determined following the method of Rubens et al. (1992). This assay is based on the inability of penicillin and gentamicin to enter epithelial cells, allowing quantification of intracellular bacteria after the extracellular bacteria have been killed.

We studied the time course of GBS (serotype III clinical isolate with its respective standard ATCC strain) invasion on HeLa and A549 cells to determine the effect of incubation time on the number of bacteria internalized or invaded into the cells (Fig. 1a and b). The maximum
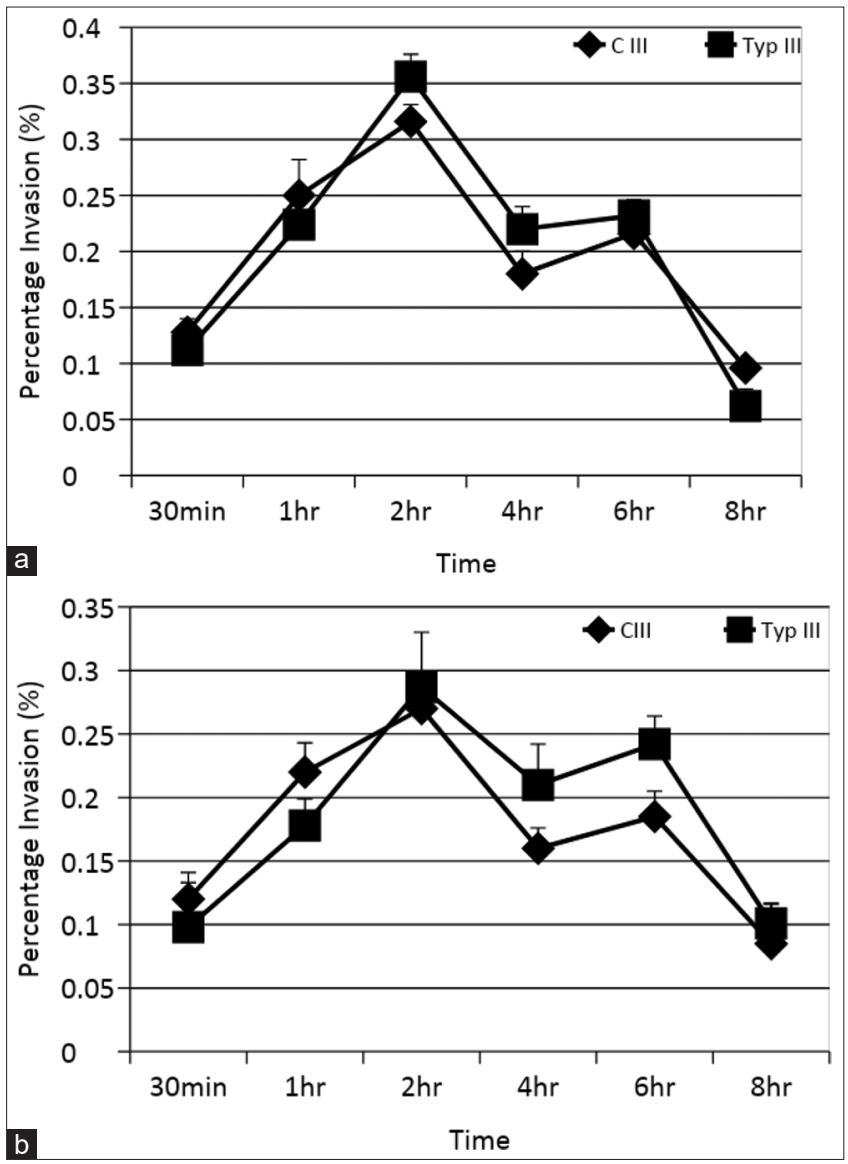

Fig. 1: Invasion of Group B Streptococcus serotype III (Standard ATCC strain=Typ III; Clinical isolate $=$ C III) at different time (30 min,1,2,4,6 and 8 h) in (a) HeLa and (b) A549 cells. Means and standard deviation (error bars) were calculated from three different experiments 

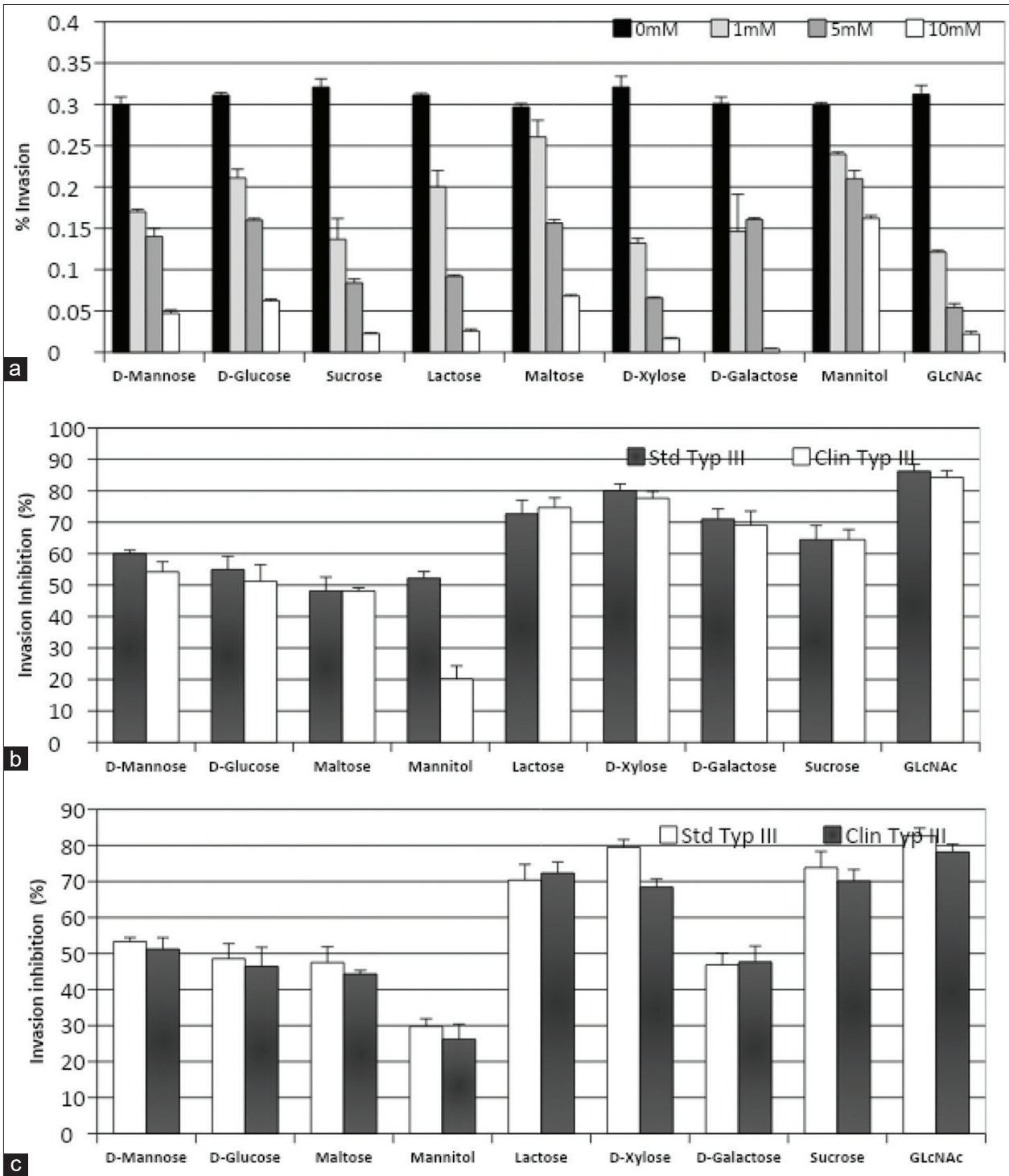

Fig. 2: Effect of various concentrations of carbohydrates on invasion of Group B streptococcus (GBS) (type III) to A549 cells (a); inhibition of type III GBS invasion to HeLa (b); and A549 cells (c) by carbohydrates at $5 \mathrm{mM}$ concentration. Means and standard deviation (error bars) were calculated from three different experiments

invasion of GBS was observed at $2 \mathrm{~h}$ which significantly decreased by $8 \mathrm{~h}(\mathrm{p}=0.002)$. However, an increased internalization in HeLa cells as compared to A549 cells at $2 \mathrm{~h}$ was demonstrated by clinical as well as the standard strain of GBS (serotype III).

\section{Invasion inhibition by sugars}

It is considered that internalization of invasive pathogens is the result of interaction of bacterial ligands with eukaryotic cell receptors, many of which are glycosylated proteins. In this study, we have used different sugars, some of which are vital surface components of Streptococcus agalactiae to competitively displace $S$. agalactiae from their attachment sites on epithelial cells during invasion. In addition, bacteria were also treated with the same sugars before infecting into the cells to study the vise-versa effect.

We tested the ability of different sugars and its compounds (D-mannose, D-glucose, sucrose, lactose, maltose, D-xylose, D-galactose, mannitol, and GlcNAc) at different concentrations (1 mM, $5 \mathrm{mM}$, and $10 \mathrm{mM}$ ) to inhibit invasion of invasive GBS serotype III in A549 and HeLa cells (Fig. 2a). In the first set of experiments, the cell lines were pretreated with different sugars before GBS invasion. Maximum invasion inhibition was observed with GlcNAc followed by xylose, sucrose, galactose, and lactose at all the concentrations. Although, a significant decrease in invasion by all the sugars was observed at a concentration of $5 \mathrm{mM}$ and $10 \mathrm{mM}$ with respect to the cells which were pretreated with PBS $(\mathrm{pH}=7.2)$ that served as control. Therefore, we further studied the invasion inhibition of all the sugars at a lower concentration of $5 \mathrm{mM}$ in A549 and HeLa cell lines (Fig. 2b and c). We observed an increase (approx. 80\%) in invasion inhibition of GBS with GlcNAc and xylose in both the cell lines; in contrast, mannitol showed a significant decrease in invasion inhibition $(\mathrm{p}<0.05)$. We further assessed the combined treatment of both GlcNAc and xylose at $5 \mathrm{mM}$ concentration on both the cell lines. Microscopic analysis showed a clear anti-adherence effect of the sugars on A549 cells when infected with GBS (Fig. 3). Quantitative analysis of invasion inhibition at different time intervals $(30 \mathrm{~min}, 1 \mathrm{~h}$, and 2 h) showed (Fig. 4) a linear decrease in invasion with increase in time of sugar pretreatment before infection in both the cell lines. The combinatorial effect of both these sugars at $2 \mathrm{~h}$ pretreatment showed $87.5 \%$ and $91 \%$ invasion inhibition with the clinical strain of GBS (serotype III) in A549 and HeLa cells, respectively. In continuation to the above experiments when the bacteria were pretreated with sugars and added to the cells with culture medium, a significant inhibition by D-glucose (79.32\%, p<0.02), GlcNAc (69.66, p<0.05), and D-mannose $(48.28 \%, \mathrm{p}<0.05)$ to GBS invasion was observed (Table 1$)$, with respect 


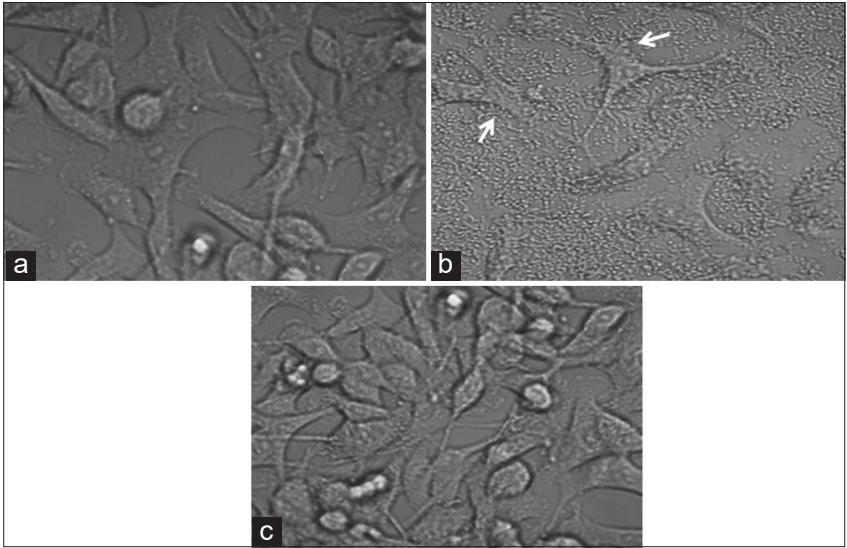

Fig. 3: Light microscopy of A549 cells treated with a combination of xylose and $\mathrm{N}$-Acetylglucosamine at $10 \mathrm{mM}$ conc. Figure (black and white) (a) shows A549 cells ( $\times 320)$, (b) untreated cells infected with Group B streptococcus (GBS) $(\times 320)$, (c) sugar treated cells infected with GBS $(\times 320)$

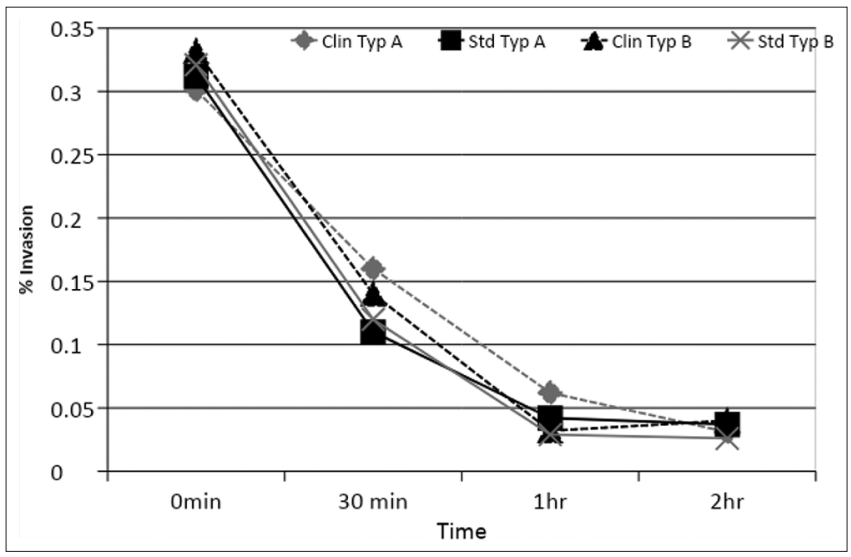

Fig. 4: Effect of time on invasion of A549 (Clin Typ A and Std Typ A) and HeLa (Clin Typ B and Std Typ B) cells after preincubation with combined effect of $\{\beta-\mathrm{N}$ acetylglucosamine+Xylose $\}$ at $5 \mathrm{mM}$ concentration

Table 1: Invasion inhibition by sugar treated Group B streptococcus at $5 \mathrm{mM}$ and $10 \mathrm{mM}$ concentration

\begin{tabular}{llc}
\hline Sugar & \multicolumn{2}{l}{ \% Invasion inhibition w.r.t control by } \\
\cline { 2 - 3 } & $\mathbf{5 ~} \mathbf{~} \mathbf{M}$ & $\mathbf{1 0 ~} \mathbf{~ M}$ \\
\hline D-Glucose & $31.04 \pm 2.28$ & $79.32 \pm 11.2$ \\
D-Mannose & $11.11 \pm 6.24$ & $48.28 \pm 4.34$ \\
N-Acetylglucosamine & $58.63 \pm 5.77$ & $69.66 \pm 6.22$ \\
\hline
\end{tabular}

anvasion assay done using gentamycin protection method, values are the mean of three separate experiments

to control (where bacteria were pretreated with PBS at the same concentration and time).

\section{DISCUSSION}

The essential step during host-pathogen interaction is the specific recognition and binding of the host carbohydrates with bacterial lectinlike proteins [15]. However, involvement of carbohydrate moieties in GBS invasion process and in its intracellular survival has not been demonstrated clearly. It is reported that GBS serotype III is the most common serotype among all other serotypes with a striking degree of virulence $[16,17]$. We studied the invasion of serotype III of GBS in both A549 and Hela cells which showed maximum internalization at $2 \mathrm{~h}$ which decreased with the increasing length of time. This may be because the organism is kept in an antibiotic-free medium and the bacteria had the opportunity to replicate in the supernatant, thus releasing more of the harmful molecules such as ß-hemolysin and proteases [10]. These molecules might, in turn, harm the epithelial cell membrane integrity with time, leading to de-adherence of epithelial cells from the substratum, making them unfit for GBS internalization. This finding was in concordance with a report by Gibson et al. [18] that reported invasion efficiency in the presence of antibiotic-free medium to be maximum at $2 \mathrm{~h}$.

Further, this study evaluated the role of various sugars on the invasion potential of the pathogen. Inhibition to GBS invasion in pretreated epithelial cells was evident from our results which showed that among all the sugars tested, GlcNAc, xylose, sucrose, galactose, and lactose inhibited GBS internalization in both the cell lines. Further, the combined exposure of GlcNAc and xylose to epithelial cells inhibited invasion maximally by $87 \%$ and $91 \%$ in HeLa and A549 cell lines, respectively. Besides, this study also showed $50 \%$ inhibition to GBS invasion by mannose ( $5 \mathrm{mM}$ ) with both the cell lines. Other saccharides such as mannitol and maltose had not much effect on GBS invasion. Similar observations were reported by Pieters [19], where almost $60 \%$ inhibition to adherence and biofilm formation of Streptococcus mutans was observed with glucose, mannose, GlcNAc, and GalNAc. Schaeffer et al. [20] also showed mannose and mannitol to inhibit adherence of Escherichia coli in uroepithelial cells. Another striking example was of sialylated complex mixture of N-linked glycoproteins which showed protection to newborn calves from a lethal dose of enterotoxigenic E. coli K99 [21]. It is also reported [22] that mannose and $\beta$-N-acetylglucosamine inhibit adherence of $E$. coli and Pseudomonas aeruginosa to epithelial cells. Our observations were also in concordance with other studies [23-25] which showed that in the presence of GlcNAc and fucose only $10 \%$ of viable intracellular GBS was observed ( $90 \%$ inhibition) followed by D-galactose and D-glucose. It is also reported that mixtures composed of variable saccharides can promote complete invasion inhibition. Galabiose (Gal $\alpha-1,4 \mathrm{Gal}$ ), a disaccharide, was shown to inhibit invasion of Campylobacter jejuni in Caco-2 cells, but no effect on its adherence was observed [4]. In another report, Gal NAc B1-4Gal could afford protection against a spectrum of bacterial and viral respiratory pathogens whereas GlcNAc alone has been reported to block binding of Burkholderia pseudomallei by $90 \%$ in A549 cells [26]. Thus, it can be said that pathogens does explore the energy metabolic pathways which play as tricks for their adherence and finally invasion into the host cells [27].

\section{CONCLUSION}

Alternative therapies for treating GBS infections are urgently needed due to the rapidly increasing occurrence of antibiotic-resistant strains. Carbohydrate analogs represent a viable alternative as their action does not require the blocking of any fundamental metabolic processes of microorganisms; hence, the emergence of resistance is unlikely. Research on such anti-adhesion therapy targeting the microbial lectins has given rise to a new era of GlycoMimetics, compounds structurally mimic the inhibitory carbohydrates which may be more assessable. Thus, this study is a step toward finding alternative adjuncts to antibiotics for the treatment of GBS infections.

\section{ACKNOWLEDGMENTS}

We would like to thank the Indian Council of Medical Research for the fellowship during this project; CSIC, Panjab University, Chandigarh, for allowing us to use the microscopic facility and Dr. H. Sodhi for providing the ATCC and clinical GBS isolates.

\section{AUTHORS' CONTRIBUTIONS}

Conceived and designed the experiments: MO, AC. Performed the experiments including invasion assays and invasion inhibition assays: 
MO. Microscopy experiments performed by MO. Analyzed the data AC and MO. Wrote and edited the paper MO, VSP, PG, and AC

\section{CONFLICTS OF INTEREST}

The authors have declared that no conflicts of interest exist.

\section{RESEARCH AND ETHIC STATEMENT}

This study has been a part of a project undertaken at PGIMER, Chandigarh, with a protocol and ethical clearance by the Institution's Ethical Committee (PGIMER, Chandigarh). This study was approved vide Ethical Clearance No. VS/1619, Dairy No. 7951-53.

\section{REFERENCES}

1. Maisey HC, Doran KS, Nizet V. Recent advances in understanding the molecular basis of Group B Streptococcus virulence. Expert Rev Mol Med 2008; 10:e27.

2. Varki A. Biological roles of oligosaccharides: All of the theories are correct. Glycobiology 1993;3:97-130.

3. Idänpään-Heikkilä I, Simon PM, ZopfD, Vullo T, Cahill P, Sokol K, et al. Oligosaccharides interfere with the establishment and progression of experimental pneumococcal pneumonia. J Infect Dis 1997;176:704-12.

4. Ganan M, Collins M, Rastall R, Hotchkiss AT, Chau HK, Carrascosa AV, et al. Inhibition by pectic oligosaccharides of the invasion of undifferentiated and differentiated Caco-2 cells by Campylobacter jejuni. Int J Food Microbiol 2010;137:181-5.

5. Beulah KC, Devi AT, Waseem K, Hedgekatte R, Prasad MN, Dhananjay BL, et al. Phyto-antiquorumones: An herbal approach for blocking bacterial trafficking and pathogenesis. Int J Pharm Pharm Sci 2015;7:27-4

6. Murugesan A, Rani S. In silico molecular docking studies on the phytoconstituents of Cadaba fruticosa (L.) Druce for its fertility activity. Asian J Pharm Clin Res 2016;9:48-50.

7. Skoff TH, Farley MM, Petit S, Craig AS, Schaffner W, Gershman $\mathrm{K}$, et al. Increasing burden of invasive Group B streptococcal disease in nonpregnant adults, 1990-2007. Clin Infect Dis 2009;49:85-92

8. Rubens CE, Smith S, Hulse M, Chi EY, van Belle G. Respiratory epithelial cell invasion by Group B streptococci. Infect Immun 1992;60:5157-63.

9. Burnham CA, Shokoples SE, Tyrrell GJ. Phosphoglycerate kinase inhibits epithelial cell invasion by Group B streptococci. Microb Pathog 2005;38:189-200.

10. Doran KS, Chang JC, Benoit VM, Eckmann L, Nizet V. Group B streptococcal beta-hemolysin/cytolysin promotes invasion of human lung epithelial cells and the release of interleukin-8. J Infect Dis 2002;185:196-203.

11. (a) Chang YC, Wang Z, Flax LA, Xu D, Esko JD, Nizet V, et al.
Glycosaminoglycan binding facilitates entry of a bacterial pathogen into central nervous systems. PLoS Pathog 2011;7:e1002082. (b) Ohri M, Parashar S, Pai VS, Ghosh S, Chakraborti A. A cytosol derived factor of Group B Streptococcus prevent its invasion into human epithelial cells. World J Microbiol Biotechnol 2018;34:45.

12. Brown JP, van Belle G, Hellström I. Design of experiments using the microcytotoxicity assay. Int J Cancer 1976;18:230-5.

13. Quintero M, Maldonado M, Perez-Munoz M, Jimenez R, Fangman T, Rupnow J, et al. Adherence inhibition of Cronobacter sakazakii to intestinal epithelial cells by prebiotic oligosaccharides. Curr Microbiol 2011;62:1448-54.

14. Nizet V, Kim KS, Stins M, Jonas M, Chi EY, Nguyen D, et al. Invasion of brain microvascular endothelial cells by Group B streptococci. Infect Immun 1997;65:5074-81.

15. Ofek I, Sharon N. Adhesins as lectins: Specificity and role in infection. Curr Top Microbiol Immunol 1990;151:91-113.

16. Baker CJ, Barrett FF. Group B streptococcal infections in infants. The importance of the various serotypes. JAMA 1974;230:1158-60.

17. Ofek I, Beachey EH. Mannose binding and epithelial cell adherence of Escherichia coli. Infect Immun 1978;22:247-54.

18. Gibson RL, Lee MK, Soderland C, Chi EY, Rubens CE. Group B streptococci invade endothelial cells: Type III capsular polysaccharide attenuates invasion. Infect Immun 1993;61:478-85.

19. Pieters RJ. Carbohydrate mediated bacterial adhesion. Adv Exp Med Biol 2011;715:227-40.

20. Schaeffer AJ, Amundsen SK, Jones JM. Effect of carbohydrates on adherence of Escherichica coli to human urinary tract epithelial cells. Infect Immun 1980;30:531-7

21. Mouricout M, Petit JM, Carias JR, Julien R. Glycoprotein glycans that inhibit adhesion of Escherichia coli mediated by K99 fimbriae: Treatment of experimental colibacillosis. Infect Immun 1990;58:98-106.

22. King SS, Young DA, Nequin LG, Carnevale EM. Use of specific sugars to inhibit bacterial adherence to equine endometrium in vitro. Am J Vet Res 2000;61:446-9.

23. Monteiro GC, Hirata R Jr., Andrade AF, Mattos-Guaraldi AL, Nagao PE. Surface carbohydrates as recognition determinants in non-opsonic interactions and intracellular viability of Group B Streptococcus strains in murine macrophages. Int J Mol Med 2004;13:175-80

24. McEwan NA, Mellor D, Kalna G. Adherence by Staphylococcus intermedius to canine corneocytes: A preliminary study comparing noninflamed and inflamed atopic canine skin. Vet Dermatol 2006;17:151-4.

25. McEwan NA, Rème CA, Gatto H, Nuttall TJ. Monosaccharide inhibition of adherence by Pseudomonas aeruginosa to canine corneocytes. Vet Dermatol 2008;19:221-5.

26. Thomas R, Brooks T. Common oligosaccharide moieties inhibit the adherence of typical and atypical respiratory pathogens. J Med Microbiol 2004;53:833-40.

27. Passalacqua KD, Charbonneau ME, O'Riordan MX. Bacterial metabolism shapes the host-pathogen interface. Microbiol Spectr 2016;4:1-20. 